\title{
A Legal Interpretation of Livy's Caudine Sponsio: Using Roman Law to test the validity of Livy's Caudine Forks Narrative
}

\author{
Michael Aston
}

Although much has been written about Livy's accoumt of the defeat of a Roman army at the hands of the Sammites at the Caudine Forks in 321 B.C., commentators do not agree as to wherher the account describes an historical event. This paper offers a new approach to the problem, by analyzing the legal form and content of the sponsio (agreement) that acts as the backbone of Livy's narrative. The body of the paper analyzes Livy's sponsio in detail. from a legal perspective. The analysis leads to the conclusion that Livy based his narrative upon the sponsio of Roman civil law. Since it is unlikely that the Romans and Sammises conducted their agreement on the basis of Roman private law, it is concluded that the events al the Caudine Forks are either fictional, or did not happen as Livy describes them.

Livy's account of the stunning Roman defeat at the Caudine Forks in 321 B.C. and the ensuing settlement is exciting and dramatic. But is it more than a well told story? Is it possible to prove or disprove Livy's account? The details of the Roman defeat recounted by Livy are well-known: a Samnite army under Gaius Pontius trapped a Roman army, under the command of consuls Spurius Postumius Albinus and Titus Veturius Calvinus, at the Caudine Forks.' The Romans and Samnites subsequently reached an agreement (sponsio), whereby the Samnites proposed release of the captured army in exchange for a treaty of peace and Roman withdrawal from Samnite territory. The Roman People, at Postumius' urging, refused to accept that Rome was bound by the agreement. The Roman parties to the sponsio were subsequently handed over to the Samnites because they were held personally responsible for making an unauthorized sponsio. Pontius refused to accept the surrendered guarantors and the treaty negotiations were brought to an end.2 Postumius and the other guarantors were released unharmed.

1 For the natnes, consulships and other refenences to Postunius and Veturius, see T. Robert S. Broughton. Dhr Mugistrates of ste Romean Republic (New York. American Ithilological Assoc.. 1951), v. I. pp. 150-151.

2 For an historiograptical andysis, see, for example, J. Lipoviky, A Hisoriogruphiral Sudy of Ijiy Books Wh.X (New York, Avro. 1981). pp. 140-148. 
Commentators are divided as to whether the Caudine Forks event happened. For some, Livy's depiction of the Caudine disaster is nothing but a fiction. ${ }^{3}$ Others accept it as historically accurate. ${ }^{4}$ Allempts to determine the accuracy of Livy's account have so far focused mainly on the relationship of the Caudine event to earlier and later events or its place in Livy's narrative. However, these approaches are inconclusive. Analysis has also been made of the relationship of the sponsio to a treaty (foedus), an issue first raised by Livy himself. ${ }^{5}$ Here too, opinions differ. Some dismiss the sponsio as a calculated substitute for a foedus, arguing that this is Livy's way of downplaying the peace agreement between the Romans and Samnites, an event that he saw as less than illustrious. ${ }^{6}$ Others consider the sponsio, like the Caudine account as a whole, seriously flawed and influenced by patriotic interests. It is not surprising, then, to find that the sponsio has been labelled a "doubtful element"7 and, at best, a "piece of legalistic special pleading." 8

Is there another way of proving or disproving Livy's account? One approach, so far untried, is to examine the sponsio from a legal perspective. ${ }^{9}$ If we can show that Livy's sponsio reflects procedures appropriate for conducting international agreements

3 See T. I. Comell's essay "The Compuest of Italy" in The Cambridge Aucient History (2d ed. Cambridge University Press. 1989\% 1. 7. pt. 2. pp. 351-419. The Second Samnile Was is covered in $\mathrm{pm}$. 368.372. The CAll finds bitule that cannow be chaltenged in the Cardine forks incident, except that the Romans suffered sonve kind of defeat. A sinulas view is given by R. M. Ogilvie in ifue introduction to Liny: Rome and haly: Books VI.X (Ir. By B. Radice. Looden. Penguia, c1982), p. 27; "... but the batule has been invested with such nunantic patlos that it is difficult to know eitter how serious the defeat really was or how grave the conseupences." Other commentators find faull with aspects of Livy's account Sec. for example, I: T. Salmon's antictes: "The Pax Caudina" (Joumal of Romass Siudies IS(1929) pp. 12-18, and "The resumption of hustilities after the Caudine Pence" (Transacrions and Procerdings of the American Philological Arsociction 87| 1956] pp. 98-108), both of which consider the aftermath of the sponsio and prohlems in Livy saccount.

4 See M. H. Crawford. "Foedas and Sprousio" (Papers of the British School as Konte, 41 (1973) pp. 1.7) for previous studies.

5 Livy writes: Consules profecti ad Pontiwn in collowuium, cen de fordere victor agitaret, negarum iniussw populi fordus fieri posse, nec sine fetialibus cuerinuoniaqur alia sollemil. haque son, ut volgo credunt Clasuliusque etiam scribit, fordere pax Caudina, sed per sponsionem farta est (9.5. IIT.). He continues by citing the reasons why the agrecinent was a sponsio and not a fordus (9.5.3-6).

6 t.jyy's biased approach to Roman treaties is well known. See: P. G Walsh. "Livy and the Aims of "flistoria": An Analysis of the Third Decade" (Aufsileg wnd Nirdergang der romischen Heh Band II. Principal, 30.2. 1982. pp. J058. (074).

7 Crawtond, p. I. See also W. B. Anderson. ed., Liny: Heok DX (13d. ed. Cambridge University Press, 1968), pp. 250. 254.

8 (AII (2d. ed. 1989), v. 7. ph. 2, p. 370. Crawforl (p. I) writes that: The imponation of the motion of sponsio was surely in fact simply an altempl to provide an adequate juridical francwork for thuse occasions when Rome repudisted a treaty and could not restore the conditions existing before the treaty was made."

The present paper dues not exantine uhether the agreement between the Romans and Santriles was reached by way of a sporsio or a fordus, or live historical basis of such an agreenent, except whene these issures ane related to legal matters that periain to the spousio.

9 Simmsio neters to a contract of agreement. Because no single tinglish tenn captures the full meaning. the latin tem is used througliout this paper. 
between Rome and other peoples c. 321 B.C., we will have evidence that effectively corroborates his description of the process followed by the Romans and Samnites at the Caudine Forks. If the process is credible, it enhances the credibility of the event. But, if we can show that the sponsio's legal form is closer to that of Roman civil law (ius civile), then the process (and thus the account) is reasonably suspect. The grounds in this case are that, while Romans sometimes applied aspects of Roman civil law to their dealings with non-Romans, it is unlikely that a major international settlement would have been resolved on the basis of civil law procedures. To test this approach, we will analyze the framework of the sponsio as Livy presents it in Book 9 of the $A b$ Urbe Condita, from the initial Roman-Samnite negotiations (9.4) to formal dissolution of the agreement (9.11), from a legal perspective. Our analysis will focus on the legal structure of Livy's sponsio with special emphasis on a comparison of its features with those of the ius civile version of the sponsio.

\section{Sources of Livy's Caudine Forks Sponsio}

Some preliminaries are in order. Livy did not invent his account of the Roman military defeat at the Caudine Forks or its aftermath. Cicero, for example, makes mention of the incident in his De Officiis (3.109). ${ }^{10}$ Having said this, what do we know about the sources of Livy's account? We may subdivide this question into two parts. First, we will consider the historical elements of the account, i.e. the entrapment of the Roman army, its surrender and the subsequent Roman-Samnite negoliations. Second, we will consider the legal sources of the sponsio, which is interwoven into the historical account.

\section{Historical Sources of the Caudine Forks Events}

Identifying Livy's sources is a notorious problem." If we consider only Book 9 of his history, that is, the text which concerns us here, commentators conjecture that Livy used the works, mostly

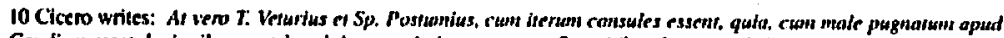

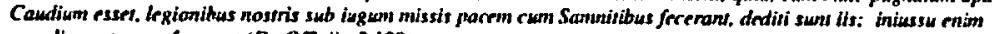
popali uenatusque fecerant (De Officiis. 3.1091.

II The literature is vast. For an intruduction. see A.E. Astin's chapter in the CAH (2d. ed.. 1989. v. 8). pp. 1.16. 
annalistic, of various historians. These historians include Valerius Antias (c. 80 B. C.), L. Calpumius Piso (Anmales), Q. Claudius Quadrigarius (Claudius, fl. during the rule of Sulla), C. Licinius Macer and L. Aelius Tubero. ${ }^{12}$ Livy also had access to public records, including the amnales maximi of the Pontifex Maximus and other archival sources. 13

Of these possible sources, we know that Livy explicitly rejected part of the historical account of the Caudine Forks incident that Claudius presented. He even gives us the reason, namely, because Claudius indicated that the agreement made by the Romans and Samnites was a foedus-a view that Livy specifically rebuffs in his account. Livy writes (9.5.2f.): itaque non, ut volgo credumt Claudiusque etiam scribit, foedere pax Caudina, sed per sponsionem facta est. The presence of the words "ut volgo credum" indicate, too, that Livy was consciously taking a position that others, namely the majority, did not support. He intimates, then, that he preferred an alternative view of things, which posited that the Caudine peace was based on a sponsio not a foedus. The works of Antias may have provided this non-traditional approach. ${ }^{14}$ Even so, we cannot say that Livy ruled out some or all of Claudius. He may well have drawn on his work for other elements of the story that suited his liking.

Since only fragments of Livy's possible sources are extant, and nothing that pertains to the Caudine Forks episode, specific influences that these historians may have had on Livy's narrative cannot be ascertained. There is another problem. Livy, or (and) his sources, may have "contaminated" the depiction of the Caudine Forks event with details taken from similar historical events. There

12 For a discussion of these sources, as well as their possible traces in Bool 9, see Anderson, pp. xvi-xx. For Anlias

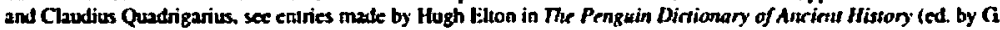
Speate. Iondon, Penguin. cl994). A useful oveniew of Roman historiography is provided by C. B. R. Itelliog in The Oxford Conjanian to Classical Chilization (ed. by S. Jomblower and A. Spawfonth. Oxford Universily Iress, 1998). pp. 346.7.

13 Anchival reconds of treaties or uther agreements are rare. One such recond cante to light in 1984. A tronze plaque recorting a drditio was uncovered in Alcantar. Spain dated IOS D.C. The docutncat (putlished in LAunte Epigraphigue. 1924. pp. 130-13]) oultioes the sumenter of the Sceani [?] to L. Caesiux in the consukhips of C. Marius and C. Flavius Fimbria The temus of the urrender are as dictaled by Caesius. The siturion. therefore, is similar to that which I ivy descrities at the Cauctine Irots, with the siden reversed. Whether livy was, or coubd lave been. aware of this reconl is unl nown. I an thankful lo a reviewer for bringing the Alcantara playute to my altention and for providing conuluents that I have paraphrased abonel.

If Crawfort p. 3. 
are two other incidents in Roman history that bear some similarity, both to each other as well as to the Caudine Forks event. 15 These events, briefly, are as follows.

The earlier incident, chronologically, pertains to the defeat of a Roman army under Marcus Atilius Regulus during the First Punic War. ${ }^{16}$ In 255 B.C., a Carthaginian army, commanded by a Spartan, Xanthippus, defeated Regulus, who, to that point, had enjoyed several victories. According to one version, the Carthaginians sent Regulus on a mission to Rome to either sue for peace or to arrange an exchange of prisoners. Regulus recommended to the Roman Senate that no deal be made with the Carthaginians. Like Postumius, Regulus returned to his captors (as he had promised). He was tortured and put to death. ${ }^{17}$

The second incident occurred (137-136 B.C.) during Roman campaigns in Spain. 18 While attempting to subdue the Aravaci in Numantia, the Roman army, under C. Hostilius Mancinus (cos. 137), was defeated. ${ }^{19}$ Mancinus tried to save the Roman army by surrendering and suing for peace. Tiberius Gracchus, at that time a quaestor serving under Mancinus, undertook the negotiations (because the Numantines trusted him). However, the Roman Senate and People refused to ratify the treaty (136 B.C.) and sent Mancinus, alone, back to the Numantines. The latter, however, like Pontius, refused to accept the Roman guarantor.

These accounts differ in details, both from each other and from Livy's Caudine Forks incident. However, there is an underlying topos of a defeated Roman army, a commander who tries to effect a

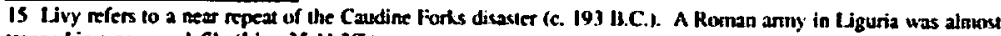
urpped in a namow defike 11 ivy 35.11 .21.).

16 Cicem deals at length with the story of Regulus in his Dr Officiis (3. 97-110). Appian (8. 1, 3-4) provides a sintilar account, in which, following his capture. Regulus is sent to Rome, nelums to Cantliage. is Iortured and dies.

17 In an alternate version. Polytius provides a full account of Regulus caunaigns and capture (1.30-34). However. in this version. nothing more is heard of Regulus after his capture. There is no memion of a nission to Rome. Regulus. he assume, dies in captivily. See H. H. Scullant (CAH, 2d. ed. 1989, v. 7, pt. 2 p. 556): "In reality he [i.e. Regulusl died tn captivity and lhe legend may have been designed to obscure the fact thal his widow fortured lwo Punic prisoners entrusted to het in Rome."

18 The accourt is taken from Ptutarch. Mberius Gracthus. 5.7. Cicens (De Officiis, 3.1091 sums up the story as follows: Qued idem multis annir post C. Mancinus, quia wh Nonantinis. quibuscum sine senaus auctoritare fovilus

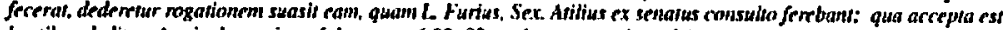
hostibus deditus. Appian's version of the story 16.80 .83 ) males no inenition of the pan played by Tiberius Gractuss. It does, how ever. point to the Caudine Forks precedent (6.83).

19 For Mancinus, see Brougtuton, v. J. p. 484.
} 
solution without the authorization of the Roman People, and the noble display of individual Roman character in accepting the consequences. The Mancinus incident is of particular interest to our present study, because the traditional account (i.e. as given above) contains an embedded reference to the Caudine Forks event. The latter, in effect, is used as a precedent in discussions held by the Senate as to what to do about the Mancinus-Numantine agreement. Since the agreement made with the Samnites by Veturius and Postumius was overturned because it depended on a sponsio, the Senate found it reasonable to nullify the efforts of Mancinus and Tiberius Gracchus on similar grounds, i.e. that Mancinus had concluded a sponsio with the Numantines, not a foedus. But was this a correct interpretation in 137-136 B.C. of what happened at the Caudine Forks in 321 B.C? Or, does the interpretation tinker with the events of 321 to suit the political requirements of the later time? For some commentators, ${ }^{20}$ the latter situation led to a re-writing of the Caudine Forks ending, i.e. the Caudine Forks story that was concocled to resolve the Mancinus problem became entangled with the original Caudine account. We are confronted, then, by the possibility of two different traditions about what happened in both the Caudine Forks and Mancinus incidents. As we have seen, Livy points to at least two versions or interpretations of the Caudine Forks incident. Fragments of the histories of Claudius and Antias indicate that there were two traditions concerning Mancinus. Antias remarks that Tiberius Gracchus made a sponsio: qui quaestor C. Mancinio in Hispania fuerat, et ceteri, qui pacem speponderamt (i.e. "had made a sponsio"). A fragment from Claudius, however, notes that commemorant Graccho foedus prior Pompeianum non esse servatum (i.e. that the treaty had not been preserved) implying that Mancinus had been involved in working on a treaty (foedus), not a sponsio. ${ }^{21}$

Livy incorporated accounts about both Regulus and Mancinus into the $A b$ Urbe Condita. The Regulus incident formed

20 Anderson, for example, finds "suspicious resemblances" between the Caudine and Mancinian acouunts and states (p. 252) that "in fact we can haslly doubt that the fonners story lass been enthellished and disfigured with details bomowed frum the later incident." 
the focal point of Book 18. The Mancinus event was contained partly in Book 55 and partly in Book 56. Unfortunately, these books are no longer extant. However, summaries of all three Books are found in the Periochae, and from these we can gain some idea of their content. $^{22}$ On the face of it, the Regulus summary matches in outline the brief description given above. The salient parts are all present. The summary (Per. 18) is silent on the question of whether Regulus attempted to secure a foedus or a sponsio, noting simply that Regulus went to Rome to either sue for peace or effect an exchange of prisoners: 1 t de pace et, si cam non posset impetrare, de commutandis captivis ageret.

In Per. 55 we read that, after a series of ill omens, Mancinus was defeated by the Numantines. He then concluded an ignominious peace that was not ratified by the Senate: pacem cum his fecit ignominiosam, quam ratam esse<senatus> veruit. In Per. 56, Mancinus is surrendered to the Numantines in order to relense the Roman People from the treaty he had arranged: ad exsolvendum foederis Numantini religione populum Mancinus, cum huius rei auctor fuisset, deditus Numamtinis non est recepms.

If the length of the original texts mirror those of the Periochae, the Mancinus account is not only split into two parts, but also forms a relatively small segment of Books 55 and 56 . This suggests, perhaps, that Livy did not delve, as he had in the Caudine Forks incident, into whether Mancinus arranged a foedus or a sponsio

21 The framents from Clatstius and Anlias are quoted by Crawfond. p. 2f. For texis, see H. W. G Peter. IIstoricorum Ramantomm Frogmenta (Lipsiae, in aeditus B. C. Teubneri, 18831: Antias Fr. 57, quoted in Gellius. 6.9.12: Claudius Fr. 73. yuoted in Priscian, 7. p. 347I.

22 For a study of the Periorhac, see W. J. Hingham A Sudy of the Lnimn Periochar and their Relation to Livy's Ab

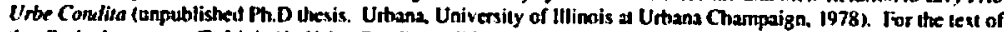
the Periorhae. sec: T. Livi Ab Urbe Condita (ediderumt W. Weissentwom [eI] M. Mueller. Periochae ontnium libronum...edidit Oto Rosshach. Stullgart. Teubnes. 1959). pt. 4.

Per. 18 indicates that the Book contained three parts. In the first pan Livy recalts Regulus feals in Africa and his enireaties to be relieved of his duties so that he may retum tome to loth after his propeny. He is defeated by the Spartan Xanthippas and taken prisoner. A Roman frect, utich could peritaps have been used to intervene. was wrecked. Al this poirt the account is internipted to describe events at Rome. In the final third of the Book. Regulus retums to Rome. He recommends rejection of the Carthaginian Ienns and retums to Canthage. as he had promi sed. to face torture and death.

The accound describing Mancinus, which sarts ahout half way through $P$ er. S5, refers to a bad omen (Quae auspicia irissia fuiste nreusu probotum est) that occurted while Mancinus was perfonning a sacrifice. There follows a single sentence that sumumarizes the sthsequent defeal of Mancinus al Ux hands of the Numantines and the disgraceful peace that he made. The Senate did not raty the peace. This ends the notes on Mancinus, and the sumnary continues with other topics. The account resumes in Per. S6. Here we find one sentence relating to Mancinus, which refers to his surnender in order to releasc the Roman People from the treaty he had made. 
with the Numantines. In addition, the summaries overlook features of the account as it appears in other sources. There is no mention of the role of Tiberius Gracchus, for example. The tone is also distinctly negative: while the Regulus summary promises a sympathetic treatment of its main character, the word "ignominious" suggests a less attractive consideration of Mancinus. ${ }^{23}$ Of special note, there is no reference in either Per. 55 or Per. 56 to the Caudine Forks incident, either as an example or precedent. It is telling, too, that the summary states that Mancinus made a foedus with the Numantines (not a sponsio). If this is correct, i.e. not an error in the Periochae, it implies that Livy drew on, or preferred, sources such as Claudius for his Mancinus narrative. He did not, therefore, bolster his account of the Caudine Forks sponsio by incorporating a reference to it in the account of the events of 137-136 B.C. Possibly, he held that Mancinus and Tiberius Gracchus were involved in a foedus, not a sponsio. However, the summary could be at fault. If we consider $P e r$. 9, we find that it is generally in agreement with the text of Book 9. But there is one important discrepancy, the summary refers to a foedus, not a sponsio, in the Caudine Forks narrative. The summary reads: idemque auctore Spurio Postumio cos., qui in senatu suaserat. ut contum deditione, quorum culpa tam deforme foedus ictum erat, publica fides liberaretur, cum duobus trib. pl. et ommibus, qui foedus spoponderant, dediti Samnitibus non sumt recepti. Did the author of the summary misread Livy, 24 or rely upon some other account? Was it a simple error? If the summary is incorrect here, can the summaries of Books 55 and 56 also contain crrors?

It is beyond the focus of this paper to explore the possible relationships between the Regulus and Mancinus stories and Livy's Caudine Forks narrative. As this brief overview indicates, attempts to decipher how such events affected Livy's account face complex

23 In contrast. for example, with (icero's estimation of Mlancinus (De Re Publicu. 3.28): si pudor quarritur, Ji

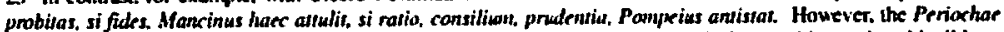
may be misleading. Ljvy considered the Caudine disaster a low, shamneful event in Roman history, but this did not detract from the noble clements in the betaviour of figures like Postumius and Veturius icf., for exanifte. Livy 25 .6.10-12).

24 The author anay have heen confused by die relerence to a forlus betueen the Rontuns and Samnites that existed before the Caudine Forhs incident. This is referenced in the opening cthapter of Bool 9. 
problems. First, the two events that we have mentioned, namely, the Regulus incident of 255 B.C. and the Mancinus incident of 137-136 B.C., are both subject to varying traditions. Second, we must consider cross-contamination, particularly with respect to the Caudine and Mancinus accounts. The Periochae provide some insights into how Livy himself dealt with the Regulus and Mancinus stories in the missing Books 18, 55 and 56 of the Ab Urbe Condita, but the Periochae are beset with their own problems of provenance. At the same time, too little remains of the sources that Livy may have used to assess their influence. The most that we can deduce thus far is that Livy chose to follow the version(s) that suited his needs and may have interwoven bits from similar historical events. such as those of Regulus and Mancinus, that were consistent with the literary topos at hand.

\section{Sources of the Sponsio}

Examination of Livy's historical sources does little to help us to clarify his account of what happened at the Caudine Forks in 321 B.C., or to determine whether he was correct in opting for a sponsio rather than a foedus. What sources, we may now ask, were available to him with respect to the legal aspect of the issue, namely, the structure and form of the sponsio? We may begin by considering briefly the legal forms of the sponsio that were known in Livy's time. Livy's Caudine sponsio arguably reflects one of two forms of the sponsio. ${ }^{25}$ The first belonged to Roman private law (ius civile) and pertained to the making of contracts between Roman citizens. It was one of the earliest instruments of the Roman laws of obligation, possibly pre-dating the Twelve Tables of 451/450 B.C. In brief, it consisted of the stipulatory exchange of a promise between the parties to a contract (stipulatio). It has been defined broadly as the “ earliest form of an obligation under ius civile through an oral answer

25 For brief legal descriptions of the sponxio, see Reinhand Zimmemiann. The Law of Obligotions: Romon

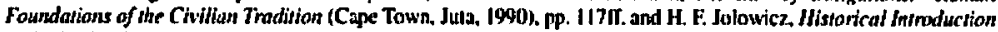

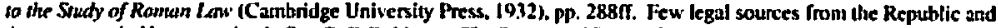
Augustan period have sun ived. See O. F. Rohinson. Dhe Sourres of Romenn Law' (New York. Roulledge, c1997) and O. Tellegen-Coupenu, A Short Jistory of Roman Law (New York, Routledge. c1993). pp. 29.62. 
("spondeo") to the future creditor's question ("spondesne"). The sponsio, conceived in this broadest sense, was in the course of time absorbed by the stipulatio." 26

As this definition indicates, the most notable characteristic of this type of sponsio is its simplicity. At a basic level, it consisted of little more than an oral agreement between two parties expressed according to certain formulas and procedures. There was no need for other parties to be present or involved, and no legal representation was required. Such a sponsio had wide contractual applications in dealings between private individuals, particularly in the areas of commerce and trade.

The second kind of sponsio pertained to international agreements. $^{27}$ There are no extant examples. However, it is reasonable to suppose that such a sponsio existed from early times as a mechanism for facilitating Rome's dealings with its neighbours and non-Roman peoples. Such a form would have been necessary, for example, particularly during the period of Roman expansion in the Italian peninsula in the fourth century B.C. This sponsio could have had a role to play in arranging the cessation of hostilities as a precursor to a formal truce or treaty. However, direct evidence for this kind of sponsio is "meagre," as one commentator remarks. ${ }^{28} \mathrm{~A}$ modern definition of such a sponsio reads as follows: "An arrangement concluded by the commanding Roman general with the enemy concerning an armistice. The commander acted on his own

26 Adolf Berger. Encyclopedic Dictionary of Roman Law (Transactions of the American Philosophical Society. New series. 43. pan 2 (1953). Philadelphia. American Philosophical Society. 1953). p. 713 b.

27 Jus genilom is used descriptively in this paper to refer to legal aclivilies involving Rome and some other, nonRoman entily. The ierm itself probably was not used before 200 B.C. (Jolowicz, p. 102, fn. 6). For an overview, see Jolowicz, pp. 100-105, and Barty Nicholas, An Iniroduction to Roman Law (Oxford. Clarendon, 1962), pp. 54-59.

The form of une Caudie sporssio has been analyzed in genteral ternus by Henri Levy-Bnuhl in his itrponant anicle. "La 'Sponsia" des Tourches Caudines" (Rewe Historique de Droil Frangais er Eranger 17| 1938], pp. 533-547). Levy-Bnhl takes the view that the Caudine amangement represenis a sponsio, rather than a foedus, and that, while it may not be entirely sccurate historically, it is an example of an international sponsto ("sponsto intemationale primitive." p. 536). Although the sponsto contains personal elentents illustrative of the private law. JÉvy-Bnuhl sees it as a form derived essentially from the public (i.e. ius gentium) form. and an early cxample of whal was later to becorne a highly personalized private law form. This approach allows hint to reconcile the "public" and "private" elemeats of the agreement.

28 Jolowicz, p. 290, stales: “...there existed outside the sphere of the ordinary civil law, a form of sponsio which was used for making treaties with foreign states, and this international fom is said to lave been originally a double onth. the regresentative of each pany swearing that the conditions of the treaty would be observed. The evidence for this theory is. However, distinctly meagre..." IEvy-Bruhl postulates that there was a generalized fom of sponsio used in intemalional dealings, based on a remart made by Postumius (p. 54 ). 
responsibility. The reciprocal duties were established through the exchange of questions and answers." 29

This "military" sponsio, if we may call it that, is difficult to identify. Gaius (Institutes. 3.94) attests to a (late?) form, but with specific reference to an arrangement conducted by the emperor and a foreign ruler. ${ }^{30}$ Because of this narrow definition, and its close association with the imperium of an emperor (consular powers are not mentioned), it is unlikely that this form corresponds to the Caudine sponsio recounted by Livy. We note at once that Livy's sponsio contains much more than an armistice. Also, because of its late date, it must be viewed as a doubtful source for the Livian sponsio. In short, a ius gentiun form of sponsio in the fourth century B.C. would have been quite different from the Gaian model. If such a form existed, where did it come from? In theory, it may have developed in one of two ways. First, it is possible that the ius civile form of the sponsio was adapted to Rome's dealings with foreign entities. Second, the ius gentium sponsio may have been derived from an older form related to Greek libation ceremonies. ${ }^{30}$ However, there is no tangible evidence that the Roman forms are derived from this source. In any event, there are no religious connotations of libation present in the sponsio, in keeping with the secular character of Roman law: ${ }^{32}$ It is equally possible that both the Latin and Greek forms may have issued from a common predecessor. ${ }^{33}$

The scarcity of extant legal sources that address the sponsio makes it almost impossible to determine what influence they may have had on Livy's ideas. ${ }^{34}$ In sum, very little is known about the

\footnotetext{
29 Berger. p. 71,3b.

30 The sponsio of the ius civile was restricted to Roman citizens. Gajus' exautple refers to the exception. Gaius

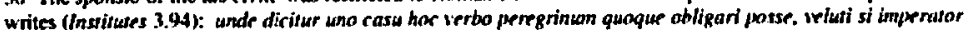
noster prinsipens alicuius perrgrini populi de pace is intermogel: paren futuram sjondes? Ifl ipse eademt utodo internogetur. Qued nimions subriliter dictum rst, quia si quid adirsus pactionem fiat non ex stipalatu agisur, evd iser belli mes viadicalur.

31 We note the etymological connection belween the (ireek spentrin (spmondai) and the Latin sponsio. 32 Alan Watson, The Spirit of Roman Law (Athens: Uaiversity of Geargia, e1995), p. 31.

31. Jolowicz p. 290. slates: "The origin of the stipulation is ltrougla by many to lie in the practice of maling promises under catll. and one of the chief arguments in favour of this view is that the word spondeo appears to lave religious associations."

34 The only extant stixdy of llice spontio, with which livy may have been acquainted, is given by Varro in tiss De Ingua Latina (6.69.72). However. Varro's interest is primarily etymological. While Varto explones the meanings of sponsio. and derivalons. in everyday Roman usage. the focus is not kgal.
} 
origins and form of a ius gentium sponsio which might help us to characterize Livy's Caudine sponsio as belonging either to international or Roman civil law. We must rely, therefore, on matching Livy's account with what is known about the ius civile sponsio and address the question as to the relationship between this legal form and the Roman-Samnite agreement described by Livy.

\section{The Sponsio in Context}

Before examining Livy's sponsio in detail it is important to note by way of an introduction that, while Livy's account outlines the substance of Roman-Samnite deliberations and pinpoints some of its major provisions, Livy does not necessarily give us the exact words that the parties used in making their deal. This puts a constraint on our ability to analyze the deal, but it does not make study of the sponsio impossible. We are still able to consider the structure of the arrangements, the process that the participants followed and examine the language that Livy uses.

With this constraint in mind, we may observe that at the centre of the Caudine negotiations is the sponsio, to which almost all of the Roman-Samnite discussions and actions are related. Livy makes it clear, however, that there are other legal issues at stake. These issues are outside the processes of the sponsio, but are worth mentioning briefly, in that they are part of the larger legal context of the Caudine passage. We can point to the following broad legal interests that feature in Livy's account: ${ }^{35}$ [i] Constitutional law: the sponsio raises [a] the constitutional issue of the power of the people's assembly and Senate to ratify treaties, and the concommitant power of consuls (i.e. their imperium) to negotiate on Rome's behalf, ${ }^{36}$ and

35 It is appreciated that the divisions and ctassifications of the Roman legal system that we male are antificial. The Tuelve Tables presert a forn of classification of the ius rivile, but oher laws were not categoriad. The ius gention and ius fetiale, for instance. were never fommlated as a written systeml.

36 Postumius makes the initial commcnt to l'ontius (9.5.1f.) that there can be no treaty without the order of tive Roman People and perfoniance of customary fetial rites. This is repeatal in this later ubless to the Senate (9.8.5). whene the states that nothing is owed to Ithe Sanunites except the persans of those who performed line sporsio. In 9.9.9f. he claims again that consuls lach the "right" lo nale peace, and had received no mandate from the Senaze:

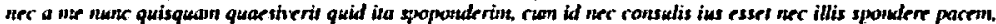

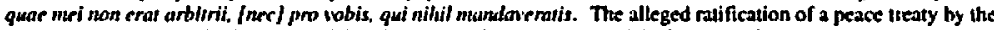
Roman People llurough its Senate, as claineed by Postumius, is controversial. G W. Housford. The Roman Arsemblies frow their Origin to the Eind of the Rrpublic (New Yort. Macinillan. 1909. pp. 302-303). points to the precelemt estahliatad by Livy's Cautine accound and ils mity. 
[b] the status of tribunes of the plebs with respect to their surrender in accordance with the sponsio (cf. 9.8.13ff); [ii] Roman military law: the Roman surrender, that forms an adjunct to the sponsio, introduces military arrangements for surrender and disarmament (the iugum procedure), deditio and truces (indutiae), ${ }^{37}$ and, finally, [iii] ius feriale: the duties of the fetial priests with respect to performing ceremonies pertaining to treaties and the sponsio. Analysis of these separate legal issues is beyond the scope of this paper, but they are mentioned here to indicate the heavy, legalistic flavouring in the Caudine Forks narrative.

\section{The Form of the Sponsio}

Livy refers to the term "sponsio" in his account, but does not define it. To analyse the Caudine sponsio, therefore, first we will identify its form (component parts and procedures) and then examine its content (scope, purpose and subject matter). We will then apply tests, each of which considers features of the Roman-Samnite agreement and how they relate to Roman laws of contract and obligation. Since the features of the civil law sponsio are well established, we may begin by comparing its features with those of Livy's account.

\section{Parties and their Roles}

In its simple form, the sponsio of the ius civile was based on a stipulatio, in which "the future creditor (stipulator) asked the future debtor (promissor) whether he was prepared to make a certain promise; the latter thereupon immediately gave this promise. ${ }^{* 38}$ In Livy's version of the Caudine sponsio, we can identify two separate parties-the Romans and the Samnites-each represented by negotiators. Pontius clearly plays the role of the stipulator, because of the Samnites' dominant position in the negotiations. The Roman representatives are the promissores. The Roman parties to the

37 We may also mention tlie legal issues stemuning from the stalus of captured Romnn soldiers and hostages and the application of posfliminisem. For a general discussion, see W. W. Buckland. The Roman law of Slarry iNew York, AMS Press, 1969), pp. 304-317.

38 Fritx Schulz, Classical Roman Law (Oxforl, Clarendun. 1951), p. 473. 
sponsio, Livy tells us, included the consuls and senior officials captured at the Caudine Forks: spoponderum consules, legati, quaestores, tribuni militum (9.5.4). Pontius is the one who sets the terms and conditions of the agreement, that the Romans must accept or reject. Thus we can say that Livy is consistent with the oral form of the stipulatio, in which we have two parties, one of whom asks for a promise and the other who gives it. The Samnites control the process, since "it is the person to whom the promise is being made who sets out the terms of the contract.",39

Livy does not tell us directly why the consuls, legates, quaestors and military tribunes were all involved as members of the Roman party to the sponsio. He alludes to the point only because it supports his contention that the peace was based on a sponsio, not a foedus: si ex foedere acta res esset, praeterquam duorum fetialium non exstarent (9.5.4). It is reasonable to argue, however, that Pontius required it, because he felt it necessary to put as many of the senior Roman officers under personal obligation as he could. This may have stemmed from the position taken by the consuls. Usually, after the Roman People had authorized a state of war, consuls had plenary powers in the field to negotiate with the enemy. On this occasion, the captured consuls effectively limited their powers by claiming that any Ireaty must be ratified by the Roman People. ${ }^{\text {to }}$ Under these circumstances, it would have been desirable, from the Samnite view, to widen the personal Roman suretyship of the sponsio in hopes that the agreement would be upheld.

\section{Verbal Format of the Sponsio}

Livy makes a point of indicating that the names of the guarantors of the sponsio are known ("and the names of all who gave the guarantee are extant" - nominaque ommium qui spopondernt

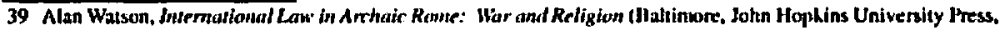
c1993). p. 32. Watson uses the differing roles of the parties as part of his prow that the foedus is not related to the ius civile. As we can sec. I jiy's approach bolsters the fact thes he is describieg a sporisio and that the sponsio is relaid to the ins chitle.

40 IEvy-Bruhl ohserves that the consuls nelain residual powers. even if they have mo received specific insinuctiun from the Senate (p. 538f.). We may note. frowever. that the cugerst factors are that [a] the consuls had been defealed and were under Samsite power and contrul. and [b] the consuls effectively waived their decision-making powen. 
exstant, 9.5.4). Whether he derived this information from his sources (more likely) or from a separate record of the sponsio is unknown. Livy does not mention whether there was a written version of the sponsio. He tells us that the terms and conditions were expressed verbally (Pontius to the Roman legates, 9.4.3-6, and again, later, in 9.5.1-6), regardless of whether the agreements were in writing. The spoken format is consistent with verbally fashioned agreements (verbis contrahitur obligatio-one of the four forms of contract) that were predominant in the early Republic. We may note that in the Caudine sponsio there were numerous witnesses to the spoken terms, both Roman and Samnite, but this was not a legal requirement and the agreement would have been legally binding without witnesses (on the principle that some god was witness to it). ${ }^{41}$

The basic (oral) form of the Roman sponsio was expressed by the sequence "spondesne?"- "spondeo."42 The language used in this formula, as Gaius indicates, was reserved for arrangements conducted among Roman citizens; it would not have been employed in dealings between Romans and non-Romans or between nonRomans (Gaius, 3.94). ${ }^{43}$ However, it was possible to use the promissory formula "do you...x?"-_"l do...x" in contractual matters between "mixed" parties (as between the Romans and Samnites). In this situation using the verb spondere would not be appropriate, but other words or expressions would be acceptable. 44 Since Livy gives us the content, but not the words, of the Caudine sponsio, we cannot know how it was phrased. We assume, however, that it contained the verbs that Livy uses to specify the sponsio's terms and conditions (i.e. decedere, abducere, etc., 9.4.4f.). This usage was also found in the ius civile: any term could be used, provided that it was used by both parties. 45

\footnotetext{
41 Schulz p. 475.

42 See, for example. Plautus, Captivi, line 808, for ane of the eartiest reconded mentions of the sponsio.

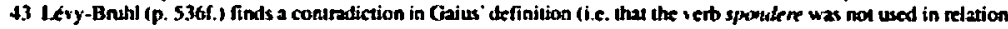
to non.Romans but could be used, if the eluperer was involved). However, (aaius is probably referring to late, classical usage. There is mo evidence that he is atluding to early Kepuhlican usage.

44 This is an exwnple of the practicalmindedness of the Ronums in finding ways of applying their law to new simalions, i.e. to peregrines.

45 Wuson, The Spirit of Romant Law, p. 22.
} 


\section{Formal Requirements of the Sponsio}

The sponsio was a device that any two or more parties could use, without the help of a lawyer or judge, for making an agreement. Despite its simplicity, there were basic rules. Three conditions had to be met.46 Does Livy's sponsio meet all the formal requirements? The first test refers to the presence and participation of the parties, namely: "The classical stipulation was an oral contract. Both parties must speak and be capable of understanding each other." ${ }^{, 47}$ Livy's narrative clearly meets this test, in that we are told that Pontius conveyed the terms and conditions to the legates, who reported them to the Roman camp. The substance of the message was previously debated by the Samnites, and later by the Romans. Both sides were fully aware of the substance and implications of the sponsio. The second test refers to the process of question and answer: "Both parties must be present during the whole act; the question must invariably come first and the answer must follow immediately." the Caudine sponsio the question (i.e. the terms and conditions) is presented to the legates (9.4.3f.) and answered by the consuls in the course of a subsequent meeting (9.5.1-6). Thus, we can say that Livy's account meets this test. Finally, "the answer must correspond precisely to the question." 49 Unfortunately, Livy does not give us the text of the sponsio, but he indicates that Pontius' terms were accepted by the Romans (spoponderim, 9.5.4). ${ }^{50}$ The Roman answer was clearly satisfactory, in that the parties concluded an agreement.

In sum, the Caudine sponsio meets the three fundamental tests that characterize the (ius civile) form: both sides were represented in the negotiations; one side took the role of stipulator and the other that of promissor; and terms were exchanged and agreed to in a simple procedure involving two leaderships.

46 The three conditions are as specified hy Sctulx, p. 473.

50 Pontius males a point of telling the legates not 10 retum if thene is something in his proposal diat they to not like: si quid conm displiceat. Iegatos redior ad se iriwit 19.4.5). This defines the proposal/yuestion. which cannot then be amended. 


\section{Contractual Terms and Conditions}

The sponsio is a form of contract. For a contract to be valid there must be some substance or thing, property or service (all of which must have some significant value) in which two or more parties have an interest. In modern legal systems this is referred to as "consideration." In the sponsio of Roman private law, the subject or thing is whatever follows the formulaic "Do you $x ?$ ?-_"I do $x$." Does the Caudine sponsio meet this test?

On the Samnite side, the ostensible object was to create a foedus with Rome that allowed them to live in peace. The main object-pax-is stated by Livy at the beginning of Book 9, with reference to the failed Samnite delegation (legati qui ad dedendas res missi eram pace infecta redierum, 9.1.3). It is repeated as one of Pontius' terms in the sponsio: alias condiciones pacis aequas victis ac victoribus fore (9.4.3). The peace is then defined by three more provisions that are essentially conditions, namely, that: [i] each side retain its own laws (suis inde legibus Romanum ac Samnitem aequo foedere victurum, 9.4.3); [ii] Rome withdraw from Samnite land (si agno Samnitium decederetur, 9.4.4), and; [iii] Rome remove its colonies from Samnite territory (/si] coloniae abdicerentur, 9.4.4). Finally, Pontius demanded that the Romans accept all three conditions. If they did not, the legates were not to return: si quid eorum displiceat, legatos redire ad se vetuit (9.4.5f.). Applying the conditions conjunctively, rather than disjunctively, left no room for negotiation: it was a take it or leave it deal that was especially hard for the Romans to accept.

There are, in addition, two ancilliary Samnite conditions: [iv] surrender of the Roman army, which will leave disarmed according to the traditional rules of war (ius belli), "under the yoke": inemes cum singulis vestimentis sub iugum missurum (9.4.3), and; [v] as a guarantee that the Romans ratify the proposed treaty, six hundred equiles are to be held under guard. The hostages are to be returned, if the treaty is ratified, but may be execuled, if it is not: et 
propter necessariam foederis dilationem obsides etiam sescenfi equites imperati, qui capite luerent, si pacto non staretur (9.5.5).

The latter conditions ([iv] and [v]) are included as part of the sponsio, but they are clearly of a different sort and not part of the treaty provisions. They [a] facilitate the formal, immediate surrender (dedirio) of the Roman army, and [b] establish the surety needed as a pledge for Roman ratification of the peace treaty. The surrender served two purposes, in that it fulfilled a Samnite condition and made possible the subsequent release of the Roman army-one of the Samnite stipulations under the agreement.

We may view the pledge as a penalty clause, common in commercial dealings, for non-performance of other stipulations in the contract. As Livy mentions later (9.15.7), the hostages are pignora pacis ("securities for the peace [treaty]"). ${ }^{51}$ The detail is significant. because it introduces a form of pledge that pertains to the ius civile. In private law, a creditor could receive from a debtor some property as a security against the debt (fiducia cum creditore). Where a contract was otherwise unenforceable, except for good faith (bona fides) between the parties, the property formed a pledge (pignus) that the conditions would be met.52 The hostages were, at this point, in the custody and control of the Samnites, but not their ownership (i.e. they were not slaves, who could be dealt with as the Samnites wished).

The Romans, as the defeated party, have little part in setting terms and conditions and Livy assigns to them a subordinate role in the negotiations. They are not in a position to impose their views. Their interests (albeit forced on them) are twofold: [i] survival of the Roman army, and [ii] peace with the Samnites (whether desirable or not) and some measure of certainty in Roman-Samnite relations. ${ }^{53}$

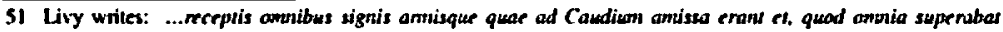
gawdia, equitibus mciperatis quas pignoru pacis custodiendos Lureriam Samuites dederant (9.15.7).

52 Berger (p. 630b) defines plgnus: "Both the thing given as a real security (pledge) to the credilor by the debtor and the pentinert agreement under whtich the securily was given...The agrement was a contract concluded re. i.e by the thelivery of the pledge to the pledgee. Pignes implies the transfer of possession (not ow rership) of the thing pledged to the creditor..." It is noted that thene is no ubligation to return the property if the agreenent is teminated. Thus, Pontius was free to do as he liked with the equiles, after the Ronans fail to kecp elueir past of tive agreemeni. Hostages as pignus are al wo found in 36.40 .4 .

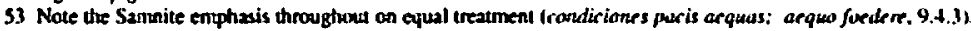


The Romans do, however, gain important concessions from Pontius, ${ }^{54}$ by making the proposed foedus subject to [i] ratification by the people and [ii] implementation according to "fetial and other customary rites": consules profecti ad Pontium in conloquium, cum de foedere victor agiraret, negarnu iniussu populi foedus fieri posse, nec sine ferialibus caerimoniaque alia sollemmi (9.5.If.). The conditions, accepted by Pontius, effectively converted the agreement from one of fact (i.e. a foedus delivered by both sides) into one of promise, i.e. something that would be concluded in the future (a contract, i.e. a civil law sponsio) and which was subject to further approval.

The terms and conditions specified by the Samnites strike the modern reader as coercive, but they are in keeping with the rights of the victor under the ius belli.55 A similar principle applied in the private law: whereas in modern legal systems the use of coercion would invalidate a private contractual agreement (both parties must be free and have legal capacity to enter a contract), the ius civile had no such requirement. ${ }^{\text {s6 }}$ A deal was a deal. However, there is no evidence that Postumius and his colleagues entered the agreement in good faith. Facing the Senate later, Postumius was only too ready to denounce the deal as unsanctioned. Postumius' handling of the sponsio was a pragmatic and self-serving way of saving the Roman army. ${ }^{57}$ Again, there was nothing legally wrong with this apparently two-faced approach to the deal. Postumius was coerced into making the sponsio and it was not necessary that he believed in the rightness of it. He was bound by it personally, but he did not have to like it. It was humiliating, but this did not lessen the bonds of obligation. ${ }^{58}$

\footnotetext{
St The concession is pertaps equivaleal to an exception (exceptiol in private law. If we imagint that the terms were taken before a istex, the condition contained in the exreptio would have to be lahen into account.

55 The point is mentioned by the Satunites themselves in tlueir discussions prior to the agreement: ut ef diminemstur (Ramonil incolomes et le ges iit iure belli victis inponementur (9.3.11).

56 Wasson. The Spirit of Romon law. p. 22.

57 Pontius rebukes the Romans for another insance of Ireaclierous dealings. It is noteworthy that the terms Pontius applies to them are legal terms used to describe the breaking of contracts: The Romans had used "Mteff" (Jurrum. 9.11.6) to retrieve hostages from Ponenna and killed to get hack the gold given to the Gauls who sasked Rome 19.11.6). They always used fraud (fmav) in iheir kegal dealings.

58 As Posiumius remarks: Arqui nom indignitas mrom sponslonis vincuhum frat $(9,9.7)$.
} 
A Unilateral Agreement

In its external form, as we have seen, the Caudine sponsio has all the legal characteristics of a unilateral (rather than a consensual) agreement; 59 that is to say, the Samnites ask for " $x$ " and the Romans promise " $x$." Under this arrangement, the Romans have duties (i.e. to fulfill the terms and conditions), but no rights, whereas the Samnites have mostly rights but no duties apart from the release of the Roman army. This unilateral character of the agreement has important ramifications later, in that it creates the possibility that one side may live up to its promises, while the other may not. The Caudine agreement finally unravels, we may argue, because the Samnites chose to keep their part of the bargain, but the Romans, on their side, failed to ratify the terms of the sponsio. Unfortunately for the Samnites, Pontius' subsequent proposal to the Romans that everything be put back to where it was before the sponsio was (rhetorical flourishes aside) impossible in practical terms. ${ }^{60}$ This unilateral form of the sponsio is additional evidence pointing to the origins of the Caudine arrangement in the civil law. In a ius gentium form of the sponsio it is reasonable to suppose that each side would have promised to honour requests of the other, in exchange for receiving the same consideration (i.e. a bilateral agreement, in which both sides give something and take something in return).

\section{Pactum}

Until now, we have been looking at the sponsio from the Roman point of view. How did the Samnites view the agreement? When Livy refers to sponsio, it is almost always in a Roman, rather than a Samnite, context. However, he is also careful to acknowledge that the Samnites had a different view. On the Samnite side, the term

59 See. for exartule. Nictiolas p. 162.

60 Pontius challenges ithe Romens to set things bach as they were at the Caudiute loots: Populum Rontanum appello.

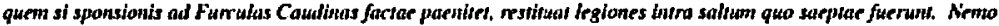

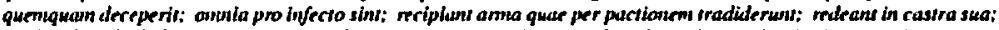

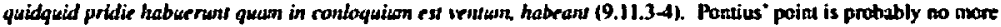
than scinging thetoric. Athurght he expected ihe Romans to ratify the deal, he held hostages against the possibility that they would not. Since there was no iudex in international aflairs, retaining the houstages in his power was the best recompense he could probably expect (in addition to any liability lec could extrast from the sponsones). The issue was legally impossible, because the sporsoors had acted ilkegally. To set things right, the Senate wouth luave been required to ratify the sponsio and then acknowitedge that Rome had violated it. 
used most often (notably by Pontius in his scathing attack on Postumius, 9.11 passim) ${ }^{61}$ is pactum (also pactio and the related verb pango). ${ }^{2}$ While both terms are part of the Latin vocabulary of the laws of contract and obligation. Livy's differentiated use in the Caudine passage suggests different approaches and interpretations by the two antagonists. We recall that one of Pontius' basic conditions was for each side to live according to its own laws (suis inde legibus, 9.4.3), demonstrating that we are dealing here with Roman and nonRoman legal systems. Etymologically, pactum is clearly related to pax (peace), connoting specifically an arrangement to end hostilities and effect a peace treaty. While this meaning fits the Caudine case, pactum has, by analogy, a more general significance that ties it to the private law, ${ }^{63}$ in that it may be used to describe almost any form of agreement (or even compromise). Pontius' address to the surrendered Postumius is, therefore, ambiguous, in that the ius civile meaning may be conflated with a Samnite understanding of the term. Depending on our interprelation, Pontius was emphasizing that there was a peace agreement struck or, more simply, that the participants had made a deal.

\section{A Matter of Obligation}

The Roman-Samnite agreement created obligations for all parties concerned, and it is this sense of obligation that is felt strongly throughout Livy's account. At the centre of the sponsio is the notion of making a stipulation (one of the simplest, oral forms of contract) under a promise. The promise is of a particular kind in that it provides a surety, or guarantee, of what is stipulated. The promisors are sponsores, a term that, as Zimmermann observes, "always scems to have been used for a person who promised for somebody else...a sponsor was al ways liable for someone else's debt." ${ }^{, 4}$ In the Caudine

61 We may nose that Pontius is aware of the differences in tentinology. He uses both sponstio and partum to describe Roman actions, trut only parion to describe his own.

62 Partion was not used by the Roanans to denote a pezce treaty. See: Gy. Dididi. Conimact in Romtan Low from the Twehe Tables to the Gloesarors (Iludapesl. Akadéniaj Kiad6. 1981). p. 119.

63 Schulr (p. 470) draws outl the meaning of "conpromtisc." to reach an understanding. which is also appropriate to Pontius" view of the Caudine arrangemenl. Watson (Law Mating in the Later Roman Republic. Oxford, Clareadon. 1974. p. (69) views the tem as applying to an agreement that has legal force.

64 Zintmermann, p. II7r. 
context, Rome is the proposed "debtor" (in Pontius' view it owes peace and other concessions), 65 the Samnites are the "creditors" and the magistrates are sureties for the debt, as expressed in the sponsio. The six hundred equites held as hostages complete the agreement. They are liable for, although they have no part in, the Senate's decision (i.e. if the treaty is rejected). They are, as in civil law, in the power and control of the creditor as a guarantee or pledge of the debtor's performance. ${ }^{66}$

Livy's understanding of the duties and responsibilities of the sponsor is extremely close to the usage of the private law. Postumius, addressing the Senate, makes it clear that he and the other Roman sponsores took part in a sponsio with the Samnites that lacked both the People's bidding and the Senate's mandate: quid enim vobiscum. patres conscripti, quid cum populo Romano actum est?... hosti nihil spopondestis, civem neminem spondere pro vobis iussistis (9.9.16f.). The promise, he claims, bound no one but the sponsores; sponsio interponeretur quae neminem praeter sponsorem obligarct (9.9.16). 67 He accepted the personal obligation entailed: Samniribus sponsores nos sumus rei satis locupletes in id quod praestare possumus, corpora nostra et animos (9.9.18). ${ }^{68}$ As sureties for the sponsio (whether properly authorized or not), the sponsores were bound by their promise and personally liable for its results. ${ }^{69}$

Watson observes that the sponsores, acting illegally, had harmed the Samnites. ${ }^{70}$ The Senate, treating them (according to the

65 Ronve is technically a "proposed" debtor, because the Senate has wot yet agreed to the sponsio, an act whicth would acknowledge its obligations.

66 For creditors and dehtor, sec. for exantple, Jolowica, p. I6/f. Livy apprecizaed the power of the creditar to "wreal vengeance" on his hostage. Prostunius declares (9.9.19): (Sanunites) in haec sarviant, in haer ferrum, in haec iras acwant.

67 Walson observes (Intemational Law, p. 36. I that the quansio could not bind the Roman People.

68 Note the tegal colouring of livy's language: reus, a defendant: pruestare. To excel," but, in an altemate sense. To keep a promise," "guarantec." conlaining an association with praes. an early form of surety.

69 Si qua obligavinus... (9.8.6); ...neninem prarter sponuom obligaret (9.9.16). The "binding is literal, as well as figurative and legal: When Posturnius and the other magistrites are handed over to Pontiu they are bound (9.10.8).

70 Commenting on the fetial declaration (9.10.9-10). Watson ohserves (Iniemational Jaw. pp. 36. 37): The expression nakem nocere or haxiam noxer "to commit a wrong" is standard in legal tatin...And whten the phrase naviom norere appeas in the Roman kegal sources, it is atways used of a stave comnuitting a wrong...Accontingly. livy's account of the dedivio of individuals is peculiarly appropriate: just as a Roman could surmencker to the victim a person in power who had contmitted a wrong (natam nocrer w without his athorization, and so release himself from all further liability, so the Roman state could surrender to the injured peopte citixens subject to its power utro had committed wrongs without authorizstion. and so relcase itsclf from all further liability." It is inferesting to note that when livy labels the Roman soldiers w/o fought at the Caudine Fords "innecent." he uses the legally favoured adjective innatius (instatios ctiom milites, 9.7.91. The peace ilself, in contrast. is hamful, noxious fex obntaviae pace, 9.10.41. 
rules of the ius civile $)^{71}$ almost in the same way that one would treat offending slaves or animals under power (i.e. in potestate), delivered them to the Samnites as a form of recompense. This action had the added purpose of removing any (religious) taint of obligation on the part of the Roman People. The position is made clear to the Samnites by the formal surrender of the bound Romans by the fetiales $(9.10 .9$ 10):

Quandoque hisce homines iniussu populi Romani Quiritium foedus ictum iri spoponderunt atque ob eam rem noxam nocuerunt, ob eam rem, quo populus Romanus scelere impio sit solutus, hosce homines vobis dedo.

This legal strand clearly satisfies Livy's need to extricate Roman honour. It is important to remember, however, that Postumius and the other sponsores were under personal obligation to Pontius on account of their part in the sponsio. They were liable to Pontius, regardless of how the Roman Senate viewed their actions. Their surrender, therefore, aclieved two purposes, satisfying both their personal obligations to Pontius and also their punishment from the Senate for their actions.

\section{Application of the Sponsio to International Agreements}

To this point we have considered the sponsio from the viewpoint of the ius civile. Is this form appropriate within the context of the international agreement described by Livy? Does it fit what we might expect of a ius gentium form of the sponsio? We have noted that here we are at a disadvantage, because there are no recorded legal definitions of a sponsio of this kind. It is useful to consider these questions by approaching the problem from the opposite direction, namely, by isolating those features of Livy's account that are unlikely elements in an international agreement. There are two important pieces of evidence within Livy's account 
that suggest strongly that this type of sponsio does not apply to the Caudine situation. The first clue is provided by the position taken by Postumius and his colleagues during the course of the negotiations. In modern administrative thinking, an official cannot properly be accountable and liable for his actions unless he has responsibility for them. The concept has been aptly defined as follows (emphasis in original):

To be responsible is to have the authority to act, power to control, freedom to decide, the ability to distinguish (as between right an wrong) and to behave rationally and reliably and with consistency and trustworthiness in exercising internal judgment. To be accountable is to answer for one's responsibilities, to report, to explain, to give reasons, to respond, to assume obligations, to render a reckoning and submit to an outside or external judgment. To be liable is to assume the duty of making good, to restore, to compensate, to recompense for wrongdoing or poor judgment. ${ }^{72}$

In the Caudine agreement, as we have seen, Postumius assumes not only personal accountability for the sponsio but also liability for the Senate's subsequent decisions and their consequences. Yet, by his own admission, he acted without having any responsibility or authority from Rome (or without any responsibility by virtue of his position) to conduct negotiations. The situation is unusual, from a Roman as well as a modern vicwpoint. How could Postumius and Veturius be accountable and liable, if they were not responsible? The situation only makes sense if we look at it as a convenient way for Livy to extricate Roman honour from the Caudine Forks disaster: he lays the blame at the consuls' feet, not Rome's. Any other form of agreement (a foedus, for example), we may argue, would not be suitable for this purpose, since Rome would then be implicated

72 Gerald E: Calden. "The Problem of linsuring the Meblic Accountability of Public Officials." in: J. G Jabbra and O. P. Dwivedi, eds. Public Senice Acrountability: A Conparative Persjective (West Hantord, Conn., Kutiusian Press, 1988), p. 25. 
directly as a participant in the negotiations. The civil law sponsio, however, furnished an accomodating vehicle for solving Livy's dilemma, in that responsibility to act (i.e. having formal authority to do so) was not a paramount feature of this kind of agreement. The motives of the participants and their intentions were not relevant to the agreement-the terms and conditions of the agreement were the important factors. The key point is that it was not necessary for Postumius and Veturius to be responsible for the content of the deal. This approach to things is confirmed by the Samnite attitude to Postumius' and Veturius' position. From Pontius' point of view the legal authority of the Roman commanders to enter into or effect a contract was irrelevant. He had made a personal deal with the Roman commanders and did, after all, have several hundred Roman hostages as security. Pontius may have believed that the Roman magistrates had authority to act and that they were acting in good faith (bona fides). From a legal aspect this was a subjective view of the agreement not an objective factor in the sponsio. Keeping the agreement was the honourable thing to do (but not necessarily the legal thing). Pontius later makes a show of castigating the Romans' bad faith, but there was no way that he could have enforced the provisions of the agreement. There was no powerful third party that could have arbitrated between them.

The second clue is provided by Livy when he outlines, through Postumius, what the "correct" (i.e. the ius gentiun?) procedure should have been to resolve the Caudine crisis:

An, si sana mens fuisset, difficile illis fuit, dum senes ab domo ad consultandum accersunt, mittere Romam legatos? Cum senatu, cum populo de pace ac foedere agere? Tridui iter expediris crat; interea in indutiis res fuisset. donec ab Roma legati aut victoriam illis certam aut pacem adferrent. Ea demum sponsio esset quam populi iussu spopondissemus (9.9.12-14). 
In this model process, which Livy presents as a reasonable way of reaching a Roman-Samnite agreement, a truce would have preserved the military situation while allowing the authorized participants on both sides to negotiate. This procedure would bring in the Roman Senate at the beginning of negotiations, rather than at the end, and also relieve the field commanders of the onerous duty of accepting personal responsibility and accountability. It is the kind of process that we would expect to find in an international agreement, i.e. an agreement made at the highest levels on both sides. In this procedure the consuls would have limited their activities to ferrying terms between Pontius and Rome. This approach, however, would have made the Roman Senate responsible and accountable for a humiliating defeat, something that Livy was reluctant to do. Livy tries to gloss over what should have been done with the excuse that it would have happened this way "if sounder minds prevailed." This overlooks that Postumius and Veturius were seasoned field commanders who, by Livy's own account in later Books, were able to negotiate freely both with the Samnites and the Roman Senate. "Sounder minds" were less necessary when the Romans were winning battles in the field and imposing their will on the conquered. In sum, the agreement that Livy depicts falls short of what we expect an international agreement to be. It is an agreement between two sides, but lacks authority on the Roman side to give it binding force.

\section{Conclusions}

The focus of this paper has been an analysis of the legal form of Livy's Caudine sponsio in order to determine whether its form can tell us anything about the genuineness of the Roman encounter with the Samnites. Three main possibilities emerge, namely, that: [i] the process followed by Pontius and Postumius in their negotiations is unique to the situation, independent of any existing international practices; this approach is tempting, apart from two main objections, namely [a] the fact that Livy himself narrows it to the process of a sponsio, and [b] the process is remarkably similar to the civil law 
form of the sponsio; [ii] the process reflects actual international practices of the time; again we must observe that [a] Livy discounts this option, in that he makes clear that it did not follow what should have been done (an si mens sana fuisset...etc.); and [b] it would imply that the ius civile form of the sponsio was virtually identical with that used in making an international agreement; finally, [iii] Livy improvised by constructing his narrative on the basis of the civil law sponsio.

Of the three options, the last is supported most strongly by Livy's text. As we have shown, the procedures followed by the Romans and Samnites in the course of their negotiations are substantially similar in form and content to those that we find in the sponsio of the Roman ius civile. If we peel away the military setting. we can see in the Caudine sponsio the structure of what could be, in other circumstances, a wholly private legal arrangement between three individuals-Pontius, Postumius and Veturius-a contract that rests ostensibly upon the personal honour (fides) of the participants, but in reality upon the Samnites' possession of Roman hostages. From the point of view of composition, we can hypothesize that Livy started with what he knew-the everyday process of the civil law sponsio-and built his narrative around it, using the structure of the sponsio as the guiding thread. This structure allowed him to place Postumius and Pontius at the heart of his story. Personalizing the agreement, he was able to explore dramatically how individual personalities and their policies were at work in the Caudine incident. ${ }^{73}$ In sum, Livy chose to show their relationship within the traditional setting of a private sponsio, with the Caudine military encounter and setting as the context and backdrop. This view is confirmed when we look for evidence of some connection between Livy's sponsio and an "international" form of an agreement. The subject matter and participants are international in scope and colouring. However.

73. The focus on Roman chancter under adversily is a fealure of all three Roman irtihtary disastess that befell the consuls at Caudium in 121 B.C. Regulus in 255 I.C and Mancinus in 137-6 B.C. And it is llese elentents of each accoina thal afe prehap the mythical or legeniary elements. Cicero is clasely attuned to the moral dimensions of these heroic figures and inclutes afl three in this De Opficiis $(3.97-110)$ as instruxtional figures who itlustrate the selliess, noble Roman citizen who kerps his word, no matter what the circumstances. 
Pontius' exclamation (9.11.9) at what Romans do in the name of "international law" (hoc tu, A. Comeli, hoc vos, feriales, iuris gentibus dicitis?) is not enough to prove that the Caudine sponsio is either a faithful representation or a fictional reconstruction of a ius gentium form. Pontius may have thought that he was conducting a deal within the meaning of international law, but the other parties 10 it did not share that thought. On the balance of the probabilities, then, it is reasonable to argue that Livy took the form of the ius civile sponsio and used it as the framework on which to build his Caudine narrative. There was a very pragmatic reason, as other commentators have observed, in that this approach conveniently allowed Livy to place the humiliating negotiations at the Caudine Forks on the shoulders of the two Roman commanders, rather than on the Roman Senate. If this view is correct, we are left to conclude cither that the sponsio at the Caudine Forks did not happen, or that it did not happen as Livy describes it. This legal analysis of Livy's account lends further support to those who view the Roman defeat at the Caudine Forks as a fictional event. 